\title{
Poetic Explorations in Bill F. Ndi's Worth Their Weight in Thorns: (De)Constructing Hegemonic National Integration and Debating Francophonecentric National Governance.
}

\author{
Hassan Mbiydzenyuy Yosimbom \\ UNIVERSITY OF GHANA, LEGON
}

Follow this and additional works at: https://docs.lib.purdue.edu/clcweb

(1)

Part of the American Studies Commons, Comparative Literature Commons, Education Commons, European Languages and Societies Commons, Feminist, Gender, and Sexuality Studies Commons, Other Arts and Humanities Commons, Other Film and Media Studies Commons, Reading and Language Commons, Rhetoric and Composition Commons, Social and Behavioral Sciences Commons, Television Commons, and the Theatre and Performance Studies Commons

Dedicated to the dissemination of scholarly and professional information, Purdue University Press selects, develops, and distributes quality resources in several key subject areas for which its parent university is famous, including business, technology, health, veterinary medicine, and other selected disciplines in the humanities and sciences.

CLCWeb: Comparative Literature and Culture, the peer-reviewed, full-text, and open-access learned journal in the humanities and social sciences, publishes new scholarship following tenets of the discipline of comparative literature and the field of cultural studies designated as "comparative cultural studies." Publications in the journal are indexed in the Annual Bibliography of English Language and Literature (Chadwyck-Healey), the Arts and Humanities Citation Index (Thomson Reuters ISI), the Humanities Index (Wilson), Humanities International Complete (EBSCO), the International Bibliography of the Modern Language Association of America, and Scopus (Elsevier). The journal is affiliated with the Purdue University Press monograph series of Books in Comparative Cultural Studies. Contact: <clcweb@purdue.edu>

\section{Recommended Citation}

Mbiydzenyuy Yosimbom, Hassan. "Poetic Explorations in Bill F. Ndi's Worth Their Weight in Thorns: (De)Constructing Hegemonic National Integration and Debating Francophonecentric National Governance.." CLCWeb: Comparative Literature and Culture 23.4 (2021): <https://doi.org/10.7771/1481-4374.3583>

This text has been double-blind peer reviewed by $2+1$ experts in the field.

The above text, published by Purdue University Press @P Purdue University, has been downloaded 0 times as of 02/10/ 22.

This document has been made available through Purdue e-Pubs, a service of the Purdue University Libraries. Please contact epubs@purdue.edu for additional information.

This is an Open Access journal. This means that it uses a funding model that does not charge readers or their institutions for access. Readers may freely read, download, copy, distribute, print, search, or link to the full texts of articles. This journal is covered under the CC BY-NC-ND license. 


\section{PURDUE}

UNIVERSITY PRESS <http://www.thepress. purdue.edu>

\section{CLCWeb: Comparative Literature and Culture}

ISSN 1481-4374 <http://docs.lib.purdue.edu/clcweb> Purdue University Press @Purdue University

CLCWeb: Comparative Literature and Culture, the peer-reviewed, full-text, and open-access learned journal in the humanities and social sciences, publishes new scholarship following tenets of the discipline of comparative literature and the field of cultural studies designated as "comparative cultural studies." In addition to the publication of articles, the journal publishes review articles of scholarly books and publishes research material in its Library Series. Publications in the journal are indexed in the Annual Bibliography of English Language and Literature (ChadwyckHealey), the Arts and Humanities Citation Index (Thomson Reuters ISI), the Humanities Index (Wilson), Humanities International Complete (EBSCO), the International Bibliography of the Modern Langua-ge Association of America, and Scopus (Elsevier). The journal is affiliated with the Purdue University Press monog-raph series of Books in Comparative Cultural Studies. Contact: <clcweb@purdue.edu>

Volume 23 Issue 4 (December 2021) Article 10 Hassan Mbiydzenyuy Yosimbom, "Poetic Explorations in Bill F. Ndi's Worth Their Weight in Thorns: (De)Constructing Hegemonic National Integration and Debating Francophonecentric National Governance" <http://docs.lib.purdue.edu/clcweb/vol23/iss4/10>

Contents of CLCWeb: Comparative Literature and Culture 23.4 (2021) <http://docs.lib.purdue.edu/clcweb/vol23/iss4/>

Abstract: This paper explores "hegemonic national integration" and "Francophonecentric national governance" in The Cameroons (TC) poetic scape. The former refers to La République du Cameroun $(L R C)$-British Southern Cameroons (BSC) or Southern Cameroons (SC) interconnectedness dominated by Francophones. The latter is governance that promotes a Francophone cultural superiority that refuses to see the Cameroonian world through Southern Cameroonians' eyes. Cameroonians live in a time of enormous fragmenting "Francophonizing" and "Anglophonizing" processes. To flesh this argument out, this paper borrows critical perspectives from Benhabib's "democratic iterations" and "deliberative democracy" and Rosenau's "six-governance typology' as requisites for good governance. It contends that "hegemonic national integration" and "Francophonecentric national governance" are pervasive features of Bill Ndi's poetry. Indeed, SC literature of the anti-Francophoncentrism kind such as Nkengasong's Across the Mongolo, Besong's Disgrace, Nyamnjoh's Souls Forgotten, etc., has not been recognized. For demonstrative purposes, focus will be on Ndi's Worth their Weight in Thorns, a glaring example of such works. TC in which the poems are set is ruled by a power-drunk elite and characterized by socioeconomic and politico-cultural marginalization which is symptomatic of "hegemonic national (dis)integration" and "Francophonecentric national governance". In TC, national integration and governance have become a kind of postcolonial re-racialization because the disparities between the wealthy/powerful Francophones and the poor/powerless Southern Cameroonians possess something akin to the racial character being witnessed in the USA. Consequently, reading Ndi's collection from this perspective reveals the ongoing rivalry between the dominant $L R C$ and the dominated SC as a stellar representation of a master-servant relationship. 
Hassan Mbiydzenyuy Yosimbom, "Poetic Explorations in Bill F. Ndi's Worth Their Weight in Thorns: (De)Constructing Hegemonic National Integration and Debating Francophonecentric National Governance in The Cameroons"

CLCWeb: Comparative Literature and Culture 23.4 (2021): <http://docs.lib.purdue.edu/clcweb/vol23/iss4/10>

page 2 of 16

\section{Hassan MBIYDZENYUY YOSIMBOM}

\section{Poetic Explorations in Bill F. Ndi's Worth Their Weight in Thorns: (De)Constructing Hegemonic National Integration and Debating Francophonecentric National Governance in The Cameroons}

\section{Introduction: The link between Ulla Brohed's "Living Library Project" and Southern Cameroons' Marginalization in The Cameroons}

In Malmö, Sweden there is a library where in addition to borrowing books, one can borrow a lesbian, a homosexual, an Imam, a Muslim woman, an animal rights activist, a Gypsy, and a journalist. According to Ulla Brohed, spokesperson for the project, the rationale for this "Living Library Project" is that a faceto-face encounter with a "representative" of a particularized identity group would be helpful in countering bigotry and preconceived stereotypes. Evidently, the "Living Library Project" extends the obvious identity markers of ethnicity, gender, sexuality, and class to include political allegiances and professional occupations because in the words of Brohed, "[y]ou sometimes hear people's prejudices and you realize that they are just uninformed" (Brohed, "Library"). The struggle to overcome prejudice remains at the heart of liberation projects based on identity, so the exercise in borrowing people from the "Living Library Project" is more than just an amusing mechanism for raising consciousness. As Carolyn D'Cruz rightly argues, "[i]t seems that at least in its stated intentions, this project presumes that knowledge gleaned from hearing about a person's lived experience, will produce a more accurate picture of those subjected to, and those who embrace, particular markers of identity with a view to transforming social relations" (1).

Knowledge of the project would spark questions as to what would happen, if the library were in The Cameroons (TC) and a library patron interested in borrowing say an Anglophone/Southern Cameroonian, got the likes of Bill Ndi, a committed Southern Cameroons (SC)/Anglophone Cameroon (AC) poet, as the representative spokesperson for Anglophone Cameroonians. Ndi is well known for his antimarginalization stance. He is author of several collections of poetry: Mishaps (2008), K'cracy (2008), Waves of Anger (2010), Bleeding Red (2010), Worth their Weight in Thorns (2014), Barbed Forest (2017), and Peace Mongers at War (2018), etc. In these collections, Ndi portrays Francophone Cameroon (FC)/La République du Cameroun ( $L R C$ ) supremacy as the cause of the oppression SC suffers. It is equally possible, however, that these borrowers might get a completely different loan - someone else. One might think of the likes of any cabinet minister of the ruling CPDM government or Ni John Fru Ndi (the Chairman of the Social Democratic Front (SDF) party) and Maurice Kamto, (the Chairman of the Cameroon Renaissance Movement (CRM) party) who claim to have won the 1992 and 2018 presidential elections, respectively.

Even though there is always room for reclassifications in a library and carpet-crossing in life, the point of reflecting on these hypothetical borrowers and lenders is that the "Living Library Project's" (just like Bill Ndi's poetry's) focus on the singular, face-to-face encounter between a self and other is a miniature contribution to the global struggles for recognition. The "Living Library Project," just like Ndi's poetry, affirms that marginalization results from individuals and groups being recognized wrongly, and this motivates the latter to correct these perceptions through recognition of identity and struggles against typecasting. Like the project, Ndi's poetic vision depicts marginality as a site of deprivation that could be turned into its opposite, what bell hooks calls a "site of radical possibility, a space of resistance ... a central location for the production of a counter-hegemonic discourse" (149). As such, Ndi does not speak of a marginality Southern Cameroonians wish "to lose - to give up or surrender as part of moving into the [Francophone] center - but rather of a site [they] stay in, cling to even, because it nourishes [their] capacity to resist, to see and create alternative new worlds" (150).

Given the socioeconomic and politico-cultural developments that have taken place in TC since independence, Francophone and Anglophone mutual interconnectedness and vulnerability have grown in diverse directions and Francophones and Anglophones no longer inhabit, if they ever did, a world of discrete circumscribed communities. Instead, they live in a world akin to what David Held calls "overlapping communities of fate" where the trajectories of all the regions of TC are deeply enmeshed with each other (1). In the Cameroonian world, "it is not only the violent exception that links people together across borders; the very nature of everyday living [connects Cameroonians] in multiple ways with increasing intensity" (1). However, the "Francophonecentric" Francophone-Anglophone interconnectedness that Cameroonians have been subjected to since independence has been one with James Ferguson's "sharp, jagged edges; rich and dangerous traffic amid zones of generalized abjection" (48). That Janus-faced/double-think interconnectedness is one "where the [nationally] networked enclave sits right beside the ungovernable humanitarian disaster zone" (48). TC's is an 
Hassan Mbiydzenyuy Yosimbom, "Poetic Explorations in Bill F. Ndi's Worth Their Weight in Thorns: (De)Constructing Hegemonic

National Integration and Debating Francophonecentric National Governance in The Cameroons"

CLCWeb: Comparative Literature and Culture 23.4 (2021): <http://docs.lib.purdue.edu/clcweb/vol23/iss4/10> page 3 of 16

interconnectedness not of national communion, "but of disconnection - not a seamless world without borders, but a patchwork of discontinuous and hierarchically ranked spaces, whose edges are carefully delimited, guarded, and enforced" ontologically and epistemologically by the Francophones" (49).

To paraphrase Ritzer, Cameroon's interconnectedness flows more easily through the FC world (although even there it flows around many areas dominated by the poor), whereas it bypasses many locales in the AC world, or even skirts them completely (11). The narrative of this asymmetrical interconnectedness has been called "national integration." TC's national integration has not been a singular, linear narrative, nor has it been a matter of pure politics. It has been linguistic, cultural, commercial, epistemological, and legal. It has been about the corruption of absolute power as well as the corruption of absolute powerlessness; it has also been about proverbial elephants fighting and the grass suffering and weirdly about elephants making love and the grass still suffering the kicks and embraces of their amorous mutual discovery. On their part, the government and governance have been hegemonically "Francophonecentric". That is, they promote a Francophone culture-boundness and superiority marked by an inability to see the Cameroonian world through the eyes of Anglophones. "Francophonecentricity" emphasizes what Malik refers to as "the right to be different" rather than "the right to be the same" (277). Both are characterized by a dualistic thinking that constructs a Cameroonian world of us (Francophones) and them (Anglophones). "Francophonecentrism" turns possibilities into either/or instead of both/and. It fosters a social reductionism that seeks to impose an identity based on one characteristic (Francophone or Anglophone) at a time when due recognition needs to be given to Cameroonian peoples' multiple identities. Ndi's poetic vision suggests that the government's ritualization of "the Francophone" and "the Anglophone" neglects the fact that the lines of dichotomizations are becoming blurrier, and Cameroonians are now questioning who, what, and where, these days, is the Francophone and cross-examining when, who, what, and where was the Anglophone.

Ndi's Worth their Weight in Thorns (WWT) attests that FC has imperiously been the center of gravity of the Cameroonian World; furthermore, the work suggests that the demotion of FC hegemony would create socio-economic and politico-cultural possibilities for the entire Cameroonian world. This paper contends that Ndi asserts that to capture the precise contours of these possibilities, Cameroonians need first to remember that, throughout Cameroon history, FC thought has tended to conceive of identity less in terms of mutual belonging (cobelonging) to a common world with AC than in terms of an asymmetrical relation between hierarchized beings. Ndi's poetic vision also affirms that it is crucial for Cameroonians to understand that Anglophoneness has played multiple roles in the imaginings of Francophone society. WWT asserts that Anglophoneness needs to be freed from the stifling enclosures of "Francophonecentric" discourse. Francophone-Anglophone relations need to be turned into a palaver, a Cameroonian community conversation that is critical, creative, and convivial, a socio-economic and politico-cultural intercourse in which the production of Cameroonian knowledges are popular public activities for a mutually interdependent Anglophone/SC and Francophone/LRC community's self-definition and social progress. From this perspective, the postulation here is to underscore that any emancipatory project to (de)construct hegemonic national integration, and any debate about the national governance complex in Cameroon, has to be a collective process involving Anglophone and Francophone experiences. Moreover, that process should be based on a complex view of Cameroonian society that understands history as a braided tapestry, archipelagos of multiple human experiences and voices/counter-voices devoid of hierarchies and free from fundamentalist and teleological Francophone certitudes.

This paper further points out that national integration/governance is fruitful when the emblematic and hypothetical imagination conceives of Anglophone and Francophone interconnectedness as peninsulas of identification. They are more like related systems of land and sea, islands and water flowing into each other, coastline and cresting wave in profound dialogism. These communities, life worlds of diverse ecologies and ethicalities, different cultures and customs, are washed by the same sheet of water, and they are deeply, if fluidly, connected by a shared sea of the history of a doublepronged colonisation. The paper concludes that Anglophones and especially Francophones need to start inviting one another in so that Cameroonians will begin to fear less, to make fewer wrong assumptions, to let go off the biases and stereotypes that unnecessarily divide them. Only then will they better embrace the ways Anglophones and Francophones are the same and the ways in which they are different, because, to borrow the words of Michelle Obama, "[t]here's power in allowing [oneself] to be known and heard, in owning [one's] unique story, in using [one's] authentic voice; [a]nd there's grace in being willing to know and hear others" (432). Reading Ndi's poetry from this perspective reveals Ndi's useful suggestion that non-hegemonic integration and non-suppositious governance can only be built on bona fide elements of moral, legal, political, cultural, economic, and epistemological cosmopolitanisms. 
Hassan Mbiydzenyuy Yosimbom, "Poetic Explorations in Bill F. Ndi's Worth Their Weight in Thorns: (De)Constructing Hegemonic

National Integration and Debating Francophonecentric National Governance in The Cameroons"

CLCWeb: Comparative Literature and Culture 23.4 (2021): <http://docs.lib.purdue.edu/clcweb/vol23/iss4/10>

page 4 of 16

Herein, (de)construction and debating are viewed as discursive strategies that challenge comfortable assumptions about Anglophone marginalization, hegemonic "Francophonecentric" national integration, and unctuous national governance in Cameroon. The ideas of (de)construction and debating in Ndi's poetic vision and in this paper begin from the claim that the current dominantly "Francophonecentric" approaches to the study of political resistance in Cameroonian politics are flawed by the fact that conceptualized forms of resistance are highly susceptible to appropriation by, or reinscription within, prevailing forms of "Francophonecentric" ordering/hierarchization. To explore how this reinscription of resistance might itself be resisted, this paper offers (de)constructed and (de)constructing accounts of political resistance developed using the poetic vision of Ndi. The (de)construction in this paper critiques the way Cameroonian governmental ordering all too quickly co-opts and engulfs resistance and tends towards onto-political totalization. The (de)constructive approach to marginalization, national integration, and national governance argues that through (de)construction, acts of resistance may be further radicalized by adding to them other onto-political critiques. The core claim made through the (de)constructive and debating mood of the paper is that though (de)construction and debating attempt to interrupt forms of thinking and knowing and processes of Francophone objectification of Anglophones and Francophone subjectification of Francophones, they can also provide valuable means by which the hegemonic gestures of onto-politics can be resisted at the levels of dehierarchized political thought and concrete praxis. (De)construction is also used in the popular parlance sense of dismantling the opinions, legitimacy, and value of "Francophonecentrism" by laying bare their superiority motives. Thus, the insertion of the prefix "de-" in parentheses means that (de)constructing marginalization, national integration, and governance involves a Schumpeterian "creative destruction" (84). That is, the processes of socio-economic and politico-cultural mutation that incessantly revolutionize the marginalization, national integration, and governance structures from within, incessantly destroying the old ones, also create new ones (84).

\section{Conceptualizing Seyla Benhabib's "Democratic Iterations" and "Deliberative Democracy" and James Rosenau's "Six-Governance Typology"}

To Benhabib, democratic iterations "are complex processes of public argument, deliberation, exchange, and learning through which universalist right claims are contested and contextualized, throughout legal and political institutions as well as in the public sphere of liberal democracies" (19). Democratic iterationists understand freedom of expression/association "not merely as citizens' political rights [but also as] crucial conditions for the recognition of individuals as beings who live in a political order of whose legitimacy they have been convinced with good reasons" (15). Democratic iterations therefore ensure that people are viewed/encountered not merely as subjects to the law but also as authors of the law. Deliberative democracy asserts that pluralist structures should not stop people from enjoying the conditions of egalitarian reciprocity, voluntary self-ascription, and freedom of exit and association (1920). It draws on three elements: egalitarian reciprocity (equal civil, political, economic, and cultural rights between minorities and majorities); voluntary self-ascription (the right to dissociate from ties imposed by birth); and freedom of exit and association. Deliberative democracy is, therefore

a model for organizing the collective and public exercise of power in the major institutions of a society on the basis of the principle that decisions affecting the well-being of a collectivity can be viewed as the outcome of a procedure of free and reasoned deliberations among individuals considered as moral and political equals (105).

Granted that we live in an era where socio-economic and politico-cultural integration and governance can no longer be conceived only in terms of external governmental control of society but emerges from a plurality of governing actors, Rosenau proposes six forms of transnational governance. The first three reflect the complex and extensive nonlinear processes that have accompanied the advent of what he calls "fragmegration" (a combination of integrating and disintegrating forces) (189). To him, "one can be called 'network' governance, another labelled 'side-by-side' governance, and still another designated as 'mobius-web' governance" (189). The second three are more straightforward, less complex and more linear and familiar sources of governance: governance-without-government or the bottom-up model (that involves the "activities of NGOs and transnational advocacy groups [that render] the governments of states mere policy ratifiers at the receiving end of the flow of authority"); governance-by-government or the top-down model ("that derive from the downward flow of authority originating within corporations or among national states and their bureaucracies"); and governance-by-market model (that stems "from the informal horizontal flows whereby economic exchanges occur in the framework of formal regulatory mechanisms") (189). To Rosenau's vision of governance just like to Ndi's poetic vision, the six- 
Hassan Mbiydzenyuy Yosimbom, "Poetic Explorations in Bill F. Ndi's Worth Their Weight in Thorns: (De)Constructing Hegemonic

National Integration and Debating Francophonecentric National Governance in The Cameroons"

CLCWeb: Comparative Literature and Culture 23.4 (2021): <http://docs.lib.purdue.edu/clcweb/vol23/iss4/10>

page 5 of 16

governance typology constitutes a vehicle for confronting the insufficiency of our ways of thinking, talking, and writing about government especially in an era "marked by shifting boundaries, relocated authorities, weakened states, and proliferating NGOs at [all] levels of community" (111). The convergence between democratic iterations, deliberative democracy and the six-governance typology is their definitional acknowledgement that sustained and disinterested collegial political debate and forthright majoritarian consensus sustain mutual interconnectedness and ensure good governance.

\section{Excavating Hegemony, Reframing and Readjusting (Dis)Integration, and Remapping (Re)Integration}

This section argues that since independence, Cameroon history has not been able to rid itself of the epistemic violence of "Francophonecentric" historiography, with its anti-"Anglophonecentric" stereotypes that resonate with what Jacques Depelchin calls "silences, the willful distortions, and denials of [AC's] historicity and humanity, its agency and autonomy" (qtd. Zeleza 1). Depelchin's Silences in African History is a powerful and timely reminder that fifty years after the Cameroonian nationalist historiographical revolt, Cameroonian socioeconomic and politico-cultural history continues to be enveloped in the "Francophonecentric" shadows of silence and subjugation. Those shadows seek to hide both the horrendous pain and costs of FC's barbarities from the Foumban Conference of 17th-21st July 1961 to the present. They equally seek to hide, to borrow Zeleza's words, "the memories of resistance and the possibilities of renewal embedded in those memories and in reconstructed pasts and futures imagined outside of [Francophone] time" (1); the memories of FC's usurpation of TC's history. "Francophonecentric" Cameroon history has continued to be guilty of commission and omission of AC stories, perpetuation of the paradigms of silencing of Anglophone voices, assertion of imperialist historiographies, unethical simplification of the Anglophone's traumatic experiences, and the epistemic excision of Anglophone polities from Cameroonian canons. This lack has also been responsible for the peripheralization/pathologization of Anglophone phenomena, the pauperizing distortions of "Anglophonecentric" development policies perpetrated by the institutional and ideological gendarmes of governance, and the dehumanizing representations of invented SC/SC in the media (Zeleza 1). Given this fictionalization, the shards of "Francophonecentric" disintegration must be excavated, the model of national integration reframed/readjusted, and a new agenda of national reintegration remapped.

In "They All Saw the Thorns", Ndi uses the image of thorns to delineate the roots and routes of hegemonic governance in Africa, especially TC. The poem thematizes the history of Africa's dismemberment through slavery/colonization, African literary writers' contributions to decolonization and the re-membering of Africa, and the AC/SC writers' strides towards "defrancophonization" and the remembering of SC. As the last poem of the collection, it is a conclusion, but at the same time, an introduction. In its 93 narrative lines, Ndi laments the advent of European hegemony and its subsequent consolidation of bad governance in Africa in the first 10 lines:

Those heralding the news styled themselves disciples

Messengers, prophets of some strange deity in the wilderness

Babbling, coaxing, cajoling

When Conrad set foot, it was still a heart of darkness

our cataclysmic omen they had in store

to despoil my people, our ways, our land sore...

That would send people to Nuremberg" (114).

Ndi's howl on how colonialists cajoled Africans, despoiled African people, their ways and land and sent them to Nuremburg reminds one of some of the brutal actions that defined this symbolic journey. For instance, Ngũgĩ reminds us that in Kenya, the British removed Waiyaki wa Hinga from his region, "the base of his power, and buried him alive at Kibwezi, head facing the bowels of the earth - in opposition to the Gĩkũyũ burial rites' requirement that the body face Mount Kenya, the dwelling place of the Supreme Deity" (3). In Xhosaland, the British captured King Hintsa of the Xhosa resistance and decapitated him, taking his head to the British Museum (Ngũgĩ 4). In 1900,

Sir Fredrick Hodgson, a British colonial governor in the then Gold Coast, demanded the surrender of the Sika'dwa (Golden Stool) - the embodiment of the Ashanti sunsum (soul) and symbol of their nationhood - so that he might sit on it, thereby triggering the great Ashanti anticolonial resistance led by Asantehene YaaAsantewaa(4).

Similarly, Cecil Rhodes wanted to be buried in the mountains, the sacred burial site of the Matabele Kings of Zimbabwe as an act of triumph and humiliation (4). 
Hassan Mbiydzenyuy Yosimbom, "Poetic Explorations in Bill F. Ndi's Worth Their Weight in Thorns: (De)Constructing Hegemonic

National Integration and Debating Francophonecentric National Governance in The Cameroons"

CLCWeb: Comparative Literature and Culture 23.4 (2021): <http://docs.lib.purdue.edu/clcweb/vol23/iss4/10> page 6 of 16

In Cameroon, Rudolf Douala Manga Bell and Ngoso Din were hanged on August 8, 1914 by the Germans, Ruben Um Nyobé was slain by the French army on September 13, 1958, Félix-Roland Moumié was assassinated by French agents in Geneva on November 3, 1960, and Ernest Ouandie was executed on January 15, 1971. The reasons for the killings in all these countries were identical: either these Africans had "treasonably/treacherously" attempted to live differently (ontological difference) or they had dared to publicly think differently (epistemological difference) from the white man. If one remembers that Nuremburg resonates with the Nuremburg trials, then Ndi's argument is that by venturing to live/think differently, the Waiyakis and Um Nyobés had committed crimes corresponding to those of the Holocaust planners (such as Adolf Hitler, Joseph Goebbels, and Heinrich Himmler) and therefore had qualified to be tried under international law. This explains why like the prosecution of prominent members of the political and military leadership of Nazi Germany who planned or participated in the Holocaust, some of these Africans were equally prosecuted. Ndi subtly makes a burlesque of colonial/international law for setting up a court to judge the likes of Hitler and Goebbels while at the same time murdering the Waiyakis and Hintsas in cold blood for simply challenging hegemony with the right to difference.

The colonialists' rejection of difference was a rejection of democratic iterations and deliberative democracy. It is as surprising as it is disappointing that these self-acclaimed institutionally enlightened nationalists/colonialists did not make any imaginative and productive institutional proposals to the Waiyakis and Hintsas. They ignored the fact that "every search for identity includes differentiating oneself from what one is not", and that "identity politics is always and necessarily a politics of the creation of difference" (Benhabib 3). Their actions displayed the atavistic belief that identities can be maintained and secured only by eliminating difference/otherness. They conceived of sovereignty as absolute or nondelegable whereas the Moumiés and Ouandies conceived it as a bundle of overlapping powers that could be divided, limited, and delegated. Given that they were "threatening people with nothingness", they could not realize that colonialism was dealing "with multiple overlapping, shifting, context-dependent individual and collective identity definitions, loyalties, solidarities, and obligations" (Benhabib 4). In terms of the "Living Library Project" mentioned earlier, one could argue that the colonial masters were only willing to borrow a white and no other lender; a uniquely universal borrowing that told everybody everywhere that there were only white masters and African slaves.

Ndi's shrewd mention of Conrad reminds us of Conrad's dramatization of such acts in Heart of Darkness, where the skulls of slain Africans decorate the walls of the Belgian colonial despot. Ndi's contention here ties in with Ngũgĩ's assertion that "the colonialists did not literally cut off the heads of the colonized or physically bury them alive. Rather, they dismembered the colonized from memory, turning their heads upside down and burying all the memories they carried" (7). Dismembered from the land, from labor, from power, and from memory, the result is destruction of the base from which the Yaa-Asantewaas and Manga Bells launched themselves into the world. Thus, after the planting of European memory, the identity of Africa became that of Europe and that explains why, even today, years after the achievement of political independence, the African continent is often identified as Anglophone, Francophone, or Lusophone and the power-drunk African elite's continued selfidentification with Franco-, Anglo-, and Lusophonism attests to the burial of the Afro under layers of Europhonism $(9,26)$. Ndi's WWT demonstrates that Cameroon's problems, especially AC's are fomented in the crucible of the Francophonism-Anglophonism asymmetry with the government consciously creating divisions among the English-speaking elite, remunerating some allies with prestigious positions in the state apparatus previously reserved for Francophones only, and repressing all actions designed to improve on the status of Anglophones. But at the end of "They All Saw the Thorns", Ndi is so optimistic that he announces the doom of oppression by promising "To bury wrong and free right" (116) thereby asserting the rejuvenescence or insurgence of Afro/Anglophone optimism.

Ndi dedicates the next 83 lines to a delineation of the multidimensionality of African literary writers' attempts at denouncing the hegemony that African governments inherited from their colonial counterparts. In a survey that begins with Armah's The Beautyful Ones and ends with Okri's The Famished Road, Ndi summarizes the commitment of more than 30 African writers. Referencing Armah, Ndi says that, "The ugly face of this universe/Armah would not paint in verse/But in prose, beautiful ones are not yet born/But in, our dictacrats have always been sworn/Yet our gardens as ever flourished with hopes/One day we shall explore their minds with probes" (114). It is not surprising that Ndi commences his survey with Armah's The Beautyful Ones given the revelations and impact Armah's novel has continued to make about postcolonial African politics through Armah's depiction of the postcolonial failure and the disillusionment that followed in the wake of Ghana's (and the rest of Africa's) independence. In the novel, the coup that overthrows a corrupt system gives the protagonist, "the Man", hope that the new people would make things right, that the new/beautiful ones would be born, only for 
Hassan Mbiydzenyuy Yosimbom, "Poetic Explorations in Bill F. Ndi's Worth Their Weight in Thorns: (De)Constructing Hegemonic

National Integration and Debating Francophonecentric National Governance in The Cameroons"

CLCWeb: Comparative Literature and Culture 23.4 (2021): <http://docs.lib.purdue.edu/clcweb/vol23/iss4/10> page 7 of 16

him to be frustrated. Ndi's citation of Armah is a reminder that like the protagonist in Armah's plot, much of Africa had hoped only to be frustrated by the new leadership that made mincemeat of democratic iterations and deliberative democracy. Though Africa has had many coups, followed by more new beginnings and births, the beautiful ones have not been born because the entire continent seems to have neglected the importance of beauty. In Ndi's poetic vision just like in Armah's novelistic vision, socioeconomic and politico-cultural beauty is conceived as a trope and the absence of that beauty denotes the modern postcolonial condition of horrid social relations, corrupt politics, and massive failure.

Furthermore, Ndi hints at a lack of (democratic) beauty by asserting that "our dictacrats have always been sworn" and therefore, beauty ceases to be a vehicle connoting freedom and ugly surroundings fail to engender beautiful configurations of self and others. Nuttal has argued that in order "to rekindle a politics of hope in Africa, there can be no better starting point than to take beauty seriously" (3). Like Armah's and Ndi's, Nuttal's is an idea of beauty that is not inhibited with fanciful abstractions that have little to do with Africa's daily concerns because almost all postcolonial Africa's misfortunes commenced the moment African communities became unable to conceive of beauty as a value. The next works referenced in Ndi's survey are Achebe's Things Fall Apart and No Longer at Ease and Soyinka's The Interpreters and Madmen and Specialists: "Then Achebe's things shall fall apart.../And won't need Soyinka's interpreters to/Tell us what madmen and specialists .../For Achebe to mock at them no longer at ease" (114). Ndi's remark that "Achebe's things shall fall apart" is an indication of his awareness that if colonialism marked the first phase of African things falling apart, then independence, with its filth, has become a second phase of things falling apart for Africans because "independence did not bring unity, social justice, peace, or prosperity, but division, inequality, political violence, and economic stagnation" (Wright 797). This explains why in Achebe's No Longer at Ease, and Soyinka's The Interpreters and Madmen and Specialists, one finds depressingly similar pictures of social and spiritual paralysis that exude pervasive pessimism and despair. In these works, democratic iterations and deliberative democracy are ignored by the first postcolonial African administrations and the states are "bankrupted by reckless overconsumption and brazen government racketeering" (798).

Within Ndi's survey, he intertextually/transtextually makes subtle references to works of two FC writers (Oyono's The Old Man and the Medal (1956) and Beti's Cruel Town (1954)), one bilingual Cameroon writer (Oyono-Mbia's His Excellency's Special Train (1979)), and several Anglophone/SC writers (Besong's Beasts of No Nation (1990), Butake's And Palm Wine Will Flow (1990), Mutia's Coils of Mortal Flesh (2008), Wakai's Fragmented Melodies (2007), Doh's The Fire Within (2008), Vakunta's Ntarikon (2008), Nyamnjoh's moniker for TC viz "Mimboland", and Ndi's Mishaps (2008), K'cracy (2008), and Bleeding Red (2010)). The unifying factor among these writers is their thematization of the neglect of democratic iterations and deliberative democracy. They all assert that the exploitative and consumption-oriented legacy bequeathed to Cameroonian leaders and public servants by the colonial administration has led them and, indeed, the people closely related to them, to look upon the independence of TC as a big opportunity to wield politico-economic power over their countrymen. They also contend that the new Cameroonian leaders see themselves as the new masters (not servants) of the Cameroonian people. Through the unity of creative difference captured amidst these writers, Ndi affirms Wright's assertion that "[d]uring the years of anticolonial struggle [Cameroon's] nationalist leaders had a better idea of what they were fighting against than of what they wanted to replace it with" (797). This explains why aside from just debunking the neglect for democratic iterations and deliberative democracy, the Anglophone/SC writers cited above take a crucial step to further assert that in the Cameroonian context, FC/LRC has elected itself to the status of a new Cameroonian master and AC/SC has been relegated to the status of a new Cameroonian bondsman. The speaker in "Between East and West" laments the birthing of that bondmanship stating that "the nimbus clouds gather/As [they] chose to stick together/Thinking [they]'d head east/Where [they]'d hoped to feast/And see no thorns/Knifing the swans" (65).

The speaker's idea of their having chosen to stick together reminds one that instead of achieving independence by joining the independent Federation of Nigeria, AC decided to achieve independence by joining the independent Republic of Cameroun. According to UN Resolution 1541 (XV) Principles VII and VIII, SC was qualified to achieve independence either through association or integration which "should be on the basis of complete equality between the peoples of the erstwhile Non-Self-Governing Territory and those of the independent country with which it is integrated" (qtd. The Bishops' Memo December $22,2016)$. It was with this understanding that on the 11th of February 1961 British Southern Cameroons (BSC) voted to join French Cameroun while British Northern Cameroons voted to join the Federal Republic of Nigeria. Unfortunately, the Ndian "nimbus clouds" that gathered foreshadowed evil and the feast the speaker and other AC had hoped for turned into thorns and the speaker who like his fellow Anglophones is fed up with marginalization, promises FC/LRC that at some point, Southern 
Hassan Mbiydzenyuy Yosimbom, "Poetic Explorations in Bill F. Ndi's Worth Their Weight in Thorns: (De)Constructing Hegemonic

National Integration and Debating Francophonecentric National Governance in The Cameroons"

CLCWeb: Comparative Literature and Culture 23.4 (2021): <http://docs.lib.purdue.edu/clcweb/vol23/iss4/10>

page 8 of 16

Cameroonians will have to depart from the union even if that departure means venturing into the turbulent sea: "When next rainy clouds your nose we see/We'll shun you devil and choose the sea/For in your hands all is grim/While in the sea we can swim/And if drowning is the way/Then let that be our doomsday" (65)!

The sea, with its daunting width and depth is a symbol of life and its hardships. The alternating calmness and sudden raging of its waves usually represent the sudden obstacles life throws our way. The most important parallelism between the sea and life in general is the unpredictability of both. That the speaker and other Anglophones/Southern Cameroonians prefer the hazardousness and unpredictability of the sea to their remaining united with Francophones/LRC is a telling image of AC/SC disappointment, disillusionment, and disgruntlement. Like its white counterpart, each time FC visits the "Living Library" it borrows only the Francophone because to it, there is only one Cameroonian story/historiography to be told and the only competent historiographer is the Francophone of $L R C$. To $L R C$, SC historiography is subaltern/noncanonical historiography and therefore has no space in the master's house because it is meant for the museum. Thus, in "Between East and West", Ndi again affirms Wright's postulation that instead of constructive political ideologies and training in multiparty parliamentary practices, Anglophones, like other Africans, have been given: "high-sounding rhetoric and nostalgic communalist myths that entrench totalitarian political systems" (798). But, unlike the protagonists in Achebe's and Soyinka's works cited earlier by Ndi, the persona in this poem and his people refuse to wearily resign themselves to $L R C^{\prime}$ 's social injustice, the duplicity of $L R C$ politicians, and the impossibility of radical change. They recognize that independence has been "a gigantic confidence trick" and a "conspiracy theory and sabotage" but are determined to fight "the personal betrayals of their leaders and parasitic government elites" (Wright 798). Ndi's persona takes their marginality "[a]s a radical standpoint/perspective/position, 'the politics of location' [from which] they participate in the formation of counter-cultural practices to identify the spaces where [AC begins] the process of revision" (hooks 15).

In "Our Story, Their History" the speaker confidently declares that history shall judge and classify "Francophonecentric" Cameroonian/global leaders as mad because they are so power-drunk that they have summarized leadership to oppression and fame: "History shall write them off all insane/For multiplying their thrones of shame/And glorifying belief in fame/ Placing all spiky crowns on the plebes" (4). In the second stanza, the speaker criticizes the international community, especially Euro-North America, for being so biased that the only moment it has ever stepped up to discipline hegemony was during the Bosnian genocide of the 1990s: "Crowns weighting the plight of Muslim Serbs/Which for once the world sat up and rushed/To clean and rid that spate with a brush" (4). On March 24, 2016, that cleaning culminated in the sentencing of former Bosnian Serb leader Radovan Karadžić to 40 years imprisonment for genocide in Srebrenica, war crimes, and crimes against humanity by the International Criminal Tribunal for the Former Yugoslavia (ICTY) and the International Court of Justice (ICJ). The speaker then underscores the double standards of the Francophone leaders/international community by asserting that: "But when same strikes lesser man down south, it doesn't crunch" (4). One of such situations where the South needed Northern intervention but was abandoned was the 1994 Rwandan genocide in which France played an aggravating role, the US resorted to minding her business under the pretext of avoiding the graphic consequences of another Battle of Mogadishu, and Israel sold guns, bullets, and grenades to the Rwandan government. (see "Rwandan Genocide," Wikipedia).

In "Our Story", the concept "South" is a loaded signifier connoting all that is not Western and presupposing a powerful "Global North" and a resistant "Global South". The term "Global South" (regions of Latin America, Asia, Africa, and Oceania) functions as more than a metaphor. It references an entire history of colonialism, neo-imperialism, and differential underdevelopment. Even though Ndi's personas and poetic vision are undoubtedly universal, one could still argue that in this context, the persona references AC/SC paradigmatically "South" thereby implying that FC/LRC is quintessentially "North". Consequently, there is a parallelism between the double-standards hegemonic relationship between the North and the South, and the doublespeak integration that binds AC/SC to FC/LRC. Just like the North has its biases when it comes to the South's predicaments, FC/LRC has continued to create and multiply thrones of shame by glorifying its belief in fame and placing all sorts of spiky crowns on the AC/SC plebes. These include the failure of successive governments of Cameroon, since 1961, to respect and implement the articles of the constitution that uphold and safeguard what BSC brought along to the union in 1961; and the cavalier management of the 1972 Referendum which took out the foundational element (Federalism) of the 1961 constitution to cite but these (see The Bishops' Memo December 22, 2016). Even though AC/SC, just like the South, has become synonymous with barbaric uncertainty, unorthodox politics, poverty, and strife, Ndi's persona is again optimistic that: "History shall raise its 
Hassan Mbiydzenyuy Yosimbom, "Poetic Explorations in Bill F. Ndi's Worth Their Weight in Thorns: (De)Constructing Hegemonic

National Integration and Debating Francophonecentric National Governance in The Cameroons"

CLCWeb: Comparative Literature and Culture 23.4 (2021): <http://docs.lib.purdue.edu/clcweb/vol23/iss4/10>

page 9 of 16

head/And question what make was that bread/To find out strangling and killing thrones/Of those lords had been shined with marrow bones" (4)!

"On Democracy" and "From yore to lore and beyond" are clear demonstrations of a contractual fascism in TC. This is one in which the power inequalities between the parties in the civil contract are such that the weaker Anglophone party, rendered vulnerable for having no alternative, is expected to accept the conditions imposed by the stronger Francophone party, however costly and despotic they may be. In the former poem, the speaker captures that fascism by lamenting that when they try to find out why their lords have never bothered about their persistent cries, they were told that either way they would go they would stray because immoral minority dictates moral majority, "As democracy projects its thorn/When over minority victory is won/And their views unquestioned trashed/With a champagne party bash/For a new reign of dictacracy/Welcomed to replace democracy/And reverse dictatorship/With gruesome predatorship" (22). To the speaker, TC's is a democracy that compels the masses to wear a crown of thorns and ensures that unjust victories are won over minorities whose views are trashed with a champagne party that mocks Benhabib's democratic iterations. Furthermore, it is a society where successive reigns of dictacracy replace deliberative democracy and transform dictatorship into predatorship. Ndi is saying that the type of integration and governance that this predatorship produces is Prospero's and not Caliban's. That Prospero's government lies in the Francophone zone/LRC, but it abides also in the Anglophone zone/SC with those intellectual and political elites who now reject their Anglophone roots and look upon the Francophone as a model to be imitated with the "Francophonecentric" blinders that distinguish the barbaric wilderness of the Francophone civilization from the Anglophone.

Ndi suggests that to combat dictatorship/predotorship, AC political thinking, far from being nationalistic, should rather be internationalistic and strengthened by an anticolonialist/anti-imperialist stance, aimed at Britain and France and at FC/LRC. The persona's assertion that in Cameroon, immoral minority dictates moral majority is an indication that there is no area of Cameroonian live including the very boundaries of Francophone-Anglophone imaginations which is not affected by the "Francophonecentric" way Cameroonian society is organized. Thus, reframing/readjusting (dis)integration and remapping (re)integration involves drastic recalibration of the machinery of Cameroonian power. That rigorous recalibration would involve, to paraphrase Ngũgĩ, debates/conversations on how and by whom power has been achieved; which class controls and maintains it; who holds or should hold power, the ends toward which the power is put, and of the possibilities of a new social order from the womb of the old $(71,76)$. Such recalibration is mandatory because, in TC like in every modern nation, there are two nations (the Francophone majority and the Anglophone minority) and two national cultures (the Francophone culture, a bourgeois culture in the form not merely of elements but of the dominant culture and the Anglophone culture, a minority culture of the toiling and the exploited whose conditions of life inevitably give rise to counterhegemonic ideologies).

This explains why in the latter poem, Ndi contends that in their thorn-pricked independence, (Anglophone/Southern) Cameroonians all stagger in dependence (23). That is, the journey to independence has been a paradoxical achievement for them because it has brought disquieting regressions, a return of the social evils that appeared to have been or about to be overcome. Following the logic of the "Living Library Project" mentioned earlier, Ndi affirms that the lenders of the "Living Library Project" of Cameroonian independence are (unfortunately) still the same as those of Cameroon's "Living Library Project" during colonial times because it is one where one should not expect to find counterhegemonists like the Besongs, Dohs, Nyamnjohs and Ndis: "A journey started long ago/Each day without breakfast/Moving from tribal yore/To their colonial lore/Completing circle with global/In which we thrive in deep dependence/Hoping day shall come for self-dependence" (23). Here, Ndi bemoans the voracious way in which hegemonic globalization, in the guise of the global, has come to devour not only promises of progress, liberty, equality, and rationality predicated on independence, but also the very idea of the struggle for these objectives. The new dependencies between the national and the global and the Anglophone and the Francophone occur in the most diverse domains of socioeconomic and politico-cultural activity.

To Ndi, the dependency situation is a circus of centers/masters and margins/slaves in which the global objectifies the national in the same manner that the Francophone thingifies the Anglophone. Goldberg suggests that if visibility results in objectification, then the marginalized could try invisibility. To him, "[i]nvisible at the margins, the marginalized [Anglophone/Southern Cameroonians] can challenge and sometimes ignore visible power at the very visible and cumbersome [Francophone] center" (199). In WWT, Ndi argues that AC's/SC's hope of one day achieving self-dependence requires a project and process of reclaiming and rewriting Anglophone/SC's history not only through critiques of 
Hassan Mbiydzenyuy Yosimbom, "Poetic Explorations in Bill F. Ndi's Worth Their Weight in Thorns: (De)Constructing Hegemonic

National Integration and Debating Francophonecentric National Governance in The Cameroons"

CLCWeb: Comparative Literature and Culture 23.4 (2021): <http://docs.lib.purdue.edu/clcweb/vol23/iss4/10> page 10 of 16

prevailing silences in $\mathrm{FC} / L R C$ historiographies, but also via vigorous reconstructions of the history of TC. "From yore to lore and beyond" is therefore an argument for the expansion of the horizons of African/TC history and independence beyond the lure of the colonial and postcolonial moment and the cartographic limits of colonial balkanization of TC into the so-called Francophones and Anglophones. The struggle to liberate Anglophone/Southern Cameroonians from living (in)dependence requires, to paraphrase Zeleza, a double intellectual maneuver: provincializing $\mathrm{FC} / L R C$ that has monopolized universality and globalizing TC beyond its "Francophonecentric" provincialization (1-2). The salience of TC's independence question raised by Ndi's poem is whether there can be an autonomous history of Anglophone/SC. That is, whether there is or can be an Anglophone/SC's history outside "Francophonecentrism", that has confronted Anglophone/SC's writers/historians, that remains to the present. Conscious of this, Ndi once more declares that the searches for "authenticity" and "autonomy" must undauntingly continue because, "We shall drive them for not shining bright/Crush the dominion for long our blight/Giving back their thorny pricked independence/Showing them our glittering strong confidence" (23).

Ndi's mapping of a counterhegemonic strategy where the dominion shall be crushed, thorny pricked independence returned, glittering strong confidence shown, tribal yore rejected, and colonial lore discarded (23), affirms that Anglophones/Southern Cameroonians have been unhomely at home. It also demonstrates the poet's understanding of the usefulness of marginality as a hooksian site of radical possibility, that space of refusal where one can say no to the hegemonists, no to the downpressor (1990:205). Ndi's idea of marginality dictates that sometimes, at a time when Anglophones know only extreme estrangement and alienation, home should be nowhere, home should no longer just be one place, it should be locations. The speaker's rejection of everything and concomitant projection of his/her "glittering strong confidence" is an affirmation that home should be that place "which enables and promotes varied and everchanging perspectives, a place where one discovers new ways of seeing reality, frontiers of difference"; a site from which "one confronts and accepts dispersal and fragmentation as part of the construction of a new world order that reveals more fully where we are, who we can become, an order that does not demand forgetting" (hooks 205). This explains why the persona in "Tell His Royal Highness" asks everyone to remind his Royal Highness and the leadership in general that, "For the love of happiness/To the top we hurtled him/Not knowing he'd mime a chimp/That done, our fate's shabbiness" (15). The idea of mimicking a chimp is a telling symbol of domination, but true to leadership humility and flexibility, the speaker promises that, "Offloading his arrogance/We will all applaud that deed/A hero he'd be indeed/For having changed at a glance" (15). The speaker then concludes that if his Highness offloads his arrogance, "his hoops and loops would be far and gone/With his thorny horn we will welcome him anew" (15). The speaker's willingness to extend a hand for forgiveness and reconciliation identifies marginality as much more than a site of deprivation; it is a site of radical possibility, but also a space of reconciliatory resistance. The speaker's reconciliatory carriage avows marginality as a "central location for the production of a counter-hegemonic discourse that is not just found in words but in habits of being and the way one lives" and lets others live (hooks 206). In the same reconciliatory posture, the persona in "My Clean Hands" declares that even if s/he were given their king to kill, "From where he could see/The crown of misery/He has birthed all his reign/Washing our hopes down the drain" (14). Thus, like the Saifs' in Ouologuem's Bound to Violence, the king has created a new breed of humiliated Anglophone/Southern Cameroonians, who are born into slavery, torture, and an imposed vocation for degradation.

\section{Constructing Subaltern Cosmopolitanism: Transgressing Francophone Cameroon's Fear and} Anglophone Cameroon's Hope

This section discusses poems that adumbrate the construction of subaltern cosmopolitanism: "the symbolic amplification of signs, clues, and latent tendencies that point to both the understanding and transformation of the [Cameroonian] world" (Santos 14). It consists of the networks and initiatives that fight against the socioeconomic and politico-cultural exclusion generated by "Francophonecentric" integration and governance (14). Granted the FC-AC power asymmetry, these initiatives and struggles involve a redistribution of socioeconomic, politico-cultural, and symbolic resources based on equality and recognition of difference (14). Subaltern cosmopolitanism's novelty lies in its deep sense of an Anglophone incompleteness that does not aim at completeness. It defends the fact that the understanding of the Cameroonian world by far exceeds the "Francophonecentric" understanding of it and that therefore, our knowledge of good governance is much less national than national integration itself. It also safeguards the fact that more non-Francophone understandings of the Cameroonian world "are being identified as it becomes more evident that there are still many others to be identified and that hybrid understandings, mixings" of Francophone and non-Francophone components, are virtually infinite (15). Subaltern cosmopolitanism thinking, therefore, stems from the idea that the diversity of 
Hassan Mbiydzenyuy Yosimbom, "Poetic Explorations in Bill F. Ndi's Worth Their Weight in Thorns: (De)Constructing Hegemonic National Integration and Debating Francophonecentric National Governance in The Cameroons"

CLCWeb: Comparative Literature and Culture 23.4 (2021): <http://docs.lib.purdue.edu/clcweb/vol23/iss4/10 page 11 of 16

the Cameroonian world is inexhaustible and that such diversity still lacks an adequate epistemology. In other words, the epistemological diversity of the Cameroonian world should not have a distinctively hegemonic Francophone or disparately subjugated Anglophone form. Using the logic of the "Living Library Project" mentioned earlier, subaltern cosmopolitanism advocates the reshuffling of a Cameroonian "Living Library Project" into a diverse one from which borrowers can walk in and borrow at random and the knowledge gleaned from hearing about the lenders' lived experiences will produce a more uniform picture of a Cameroonian world wherein national integration is non-hegemonic and governance is deliberative.

In all the poems in WWT, the personae demonstrate different degrees of subaltern cosmopolitan awareness, but the outstanding ones are: "Soliciting the Crown", "Fifty Years of Hell", "Ancestors from France", "Crown of Plenty", and "Dream On! We'll be Loyal". "Soliciting the Crown" sows the seeds for subaltern cosmopolitanism in WWT because through it, the speaker berates the Cameroon leadership for having made fake promises to the people: "Under the thorny fruit trees where we stood/And he showered all with pledges none understood/Till to the tree top he was propelled;/Where he fertilized the thorns that repel/For one quarter century sitting there like an owl/We watch him in awe, waiting he falls like a ball" (1). Through the image of a leader sitting like an owl on top of a tree with fertilized thorns that repel, Ndi reminds us that since independence Cameroonian leaders - depicted as owls - have continued to enjoy godlike invulnerability and white-imitative aspirations to bourgeois comforts and class hierarchies. The intended inference is that the leader's gruesome catalogue of terror will come to an end when the leader "falls like a ball" (Ndi 1). To the speaker in "Fifty Years of Hell", it is not just the 25 years of the leader's reign that have been a catastrophe, the entire 50 years of independence have been a descent into hell, because the story of their life has not been "written down with gold" (99). Also, they have lived a life of quantity and not one of quality, "With fifty years of hell/All hidden too, too well/In many lines glorifying not one event" (99)! Even though the speaker in "Fifty Years of Hell" condemns the glorification of a single event (possibly the celebrations marking the 50th Anniversary of the Reunification in Buea from February 18-22, 2014), the argument here is not that it is wrong to celebrate national days. The speaker's argument, which is also an AC/SC subaltern cosmopolitan argument, is that biased/particularized ccommemorations can be a mixed bag of divisiveness. Paul Biya himself acknowledged this when during his 50th anniversary speech, he recognized Buea as a spatiotemporal historiographic palimpsest: "History has not forgotten that Buea was the headquarters of West Cameroon, the capital of [SC], and the capital of German Cameroon" (February 20, 2014).

The speakers in both poems survive 25 and 50 years of marginalization, respectively, thanks to the birthing of top-notch subaltern cosmopolitanism that is at once the source of a FC/LRC fear of being toppled and a platform for an AC/SC hope that is part of the arduous task of rescuing AC/SC history from the burdens and blindfolds of "Francophonecentric" historiography. The determination to see the king fall from the treetop like a ball and that of writing an unorthodox history of TC are acts of subaltern cosmopolitanism that constitute counter-hegemonic integration and governance. As victims of discrimination, the speakers need equality that can only be birthed through subaltern cosmopolitanism. As socially excluded victims of hegemonic integration, they need a subaltern cosmopolitanism that is a counter-hegemonic integration. The longing for a Cameroonian story "told and written down with gold" (99) is a subaltern cosmopolitan call for a Francophone-Anglophone hybridization which to Bakhtin "... is not only double-voiced and double-accented but is also double-languaged" (360). That hybrid would mark the collision between differing points of view on the Cameroonian world, it would be a hybrid pregnant with potential for new world views and new internal forms for perceiving the global world through the Cameroonian local.

In "Ancestors from France" and "Crown of Plenty" Ndi's speakers further attempt to convert the "Francophonecentric" Cameroonian landscape of suppression into a vast field of lively, rich, innovative social experience. In the former poem, the speaker rejects the imposition of French ancestry on his/her people: "Ignorant ignorance...praised ancestors from France/And this song 'Nos ancêtres les gaulois'/Echoes wrong/'Coz ours is a 'continent noir'/Refusing ancestor from France" (98). Here, Ndi focuses on an aspect of subaltern cosmopolitanism called "ruin seeds" (Santos 29). By rejecting the leadership's song "Nos ancêtres les gaulois", the speaker educes "an absent present, both Cameroonian memory and alternative future at one and the same time" (29). The rejection of French ancestry and the willful recognition of a "continent noir" symbolizes ruin seeds; all that AC acknowledges as AngloSaxon culture, which, though having been historically suppressed by "Francophoncentrism", remains alive in AC memory, and alienated live as shibboleths of hope for a post-Francophonecentric future. As happens with ruins in general, here too there is some nostalgia for a past before the unjust suffering caused by "Francophonecentrism" (30). Such nostalgia is experienced as an antinostalgic mode; "guidance toward a future that escapes the collapse of the ["Francophonecentric"] alternatives precisely 
Hassan Mbiydzenyuy Yosimbom, "Poetic Explorations in Bill F. Ndi's Worth Their Weight in Thorns: (De)Constructing Hegemonic

National Integration and Debating Francophonecentric National Governance in The Cameroons"

CLCWeb: Comparative Literature and Culture 23.4 (2021): <http://docs.lib.purdue.edu/clcweb/vol23/iss4/10> page 12 of 16

because it has always been outside such alternatives" (30). Even though "the blame whole we are slack" metaphorically reminds one of the "Francophonecentric" labelling of Anglophones as radicals, what Ndi suggests is that we cherish "ruins that are alive, not because they are visited by living people but because they are lived by people that are very much alive in their practice of resistance and struggle for an alternative future. They are, therefore, both ruins and seeds at the same time" (30).

Nonetheless, the poem is a stringent call for dewesternization, a heterogeneous multipolar set of responses disputing the unipolar management of the Cameroonian world by France. By rejecting French ancestry, the speaker asserts that uni-polarity was/has only been successful in enacting the French designs associated with Westernization. Meanwhile subaltern cosmopolitan multipolarity "fractures ['Frenchification'] by delinking Cameroonians from French domination (Mignolo, 2018: xiii). Dewesternization is a call for a revision of conversational terms between France and Cameroon and consequently between FC/LRC and AC/SC. Dewesternization disputes the control of the colonial matrix of power (which has metamorphosed into a FC/LRC power matrix) and relinks Cameroonians with memories and thinking that were disavowed by the colonial power matrix. It leads to a multipolar Cameroonian world with pluriversal options by pushing aside the pretended universality of the French local histories (Mignolo 105). That the speaker and his Anglophone community refuse to dance and praise ancestors from France is a subaltern cosmopolitan message that alternative visions of and pathways toward a multipolar and pluriversal horizon in the Cameroonian national order are emerging out of the local histories and sensibilities that have endured the humiliation and subjugation of the Francophone matrix of power (106). "Ancestors from France" is, therefore, about breaking hierarchies of difference, producing counter-discourses/knowledges/practices that seek to dismantle Gallicism and its outgrowth, "Francophonecentrism".

In "Crown of Plenty" the speaker contends that "The lion surrounded by its pride/Makes sure he and his are of blight/Free in an ocean of plenty/Far from... festooned scarcity" but in their case, "The shadow of the kings' crown of plenty" is "The reflection of our dire scarcity" (42). It is, "Their crown of plenty/With wild thorns plenty/Skilfully worn by these royals/Of hopes full masses were loyal" (42). Rosenau has argued that in every society, there are alternative citizen roles to be performed (284). To him, those who prioritize their own needs over their collectivity's practice self-centered citizenship. Citizens who hierarchize their collectivity's needs over theirs practice either altruistic or ideological citizenship. People who "attach little political significance either to their own or their collectivity's needs" practice apathetic or alienated citizenship" (Rosenau 284). Finally, individuals "who invest deeply in the realization of both theirs and their collectivity's needs practice democratic citizenship". The fact that the shadow of the kings' crown of plenty reflects his subjects' dire scarcity and that their crown of plenty has wild thorns plenty demonstrate that the king in connivance with his power-drunk elite group practices self-centered citizenship. In line with the dictates of democratic iterations and deliberative democracy, one would have expected a king who wears a crown of plenty to practice a balanced combination of altruistic, ideological, and democratic citizenships but the king has rather chosen a bizarre combination of self-centered and apathetic or alienated citizenships. He has become the state not in a Louis XIV positive transformation sense but in the Joseph Stalin or Idi Amin Dada sense of dehumanizing the peasantry.

However, the people have decided to be disloyal to him, "Loyalty, plentiful we shall make scarce/For their crown of plenty we have as curse" (Ndi 42). This ties in with what subaltern cosmopolitans call counterhegemonic appropriations. That is, concepts and practices such as law, human rights, democracy, and the constitution "developed by dominant social groups to reproduce domination, but which are appropriated by oppressed social groups and then re-signified, subverted, and selectively/creatively changed so as to be turned into tools for struggles against domination" (Santos 31). In this case, law, human rights, and democracy have been appropriated because the speaker's people are making use of their democratic right to protest. In line with the AC protests that have been going on in TC since 1964 and have escalated since October 2016, the speaker feels that the lion surrounded by its pride has failed to make sure he and his are free in an ocean of plenty and far from festooned scarcity (Ndi 42). Disloyalty is therefore a demand for a shift in the frame and perspective of hegemonic national integration to one that is innovative and positive. It offers perhaps the possibility to challenge the political Francophone paradogmas of the past and their imperial and dependence-based designs and aspirations. Given that the jinx of the AC/SC dependency theory is no longer bearable, Anglophone liberated zones would be consensual communities and educational in nature because they would enable the speaker and his people to view them as realist utopias or, better still, heterotopias. Thus, the speaker is a revolutionary worker from within the popular culture striving to lead AC to its own cultural affirmation through anti-ideological veracity, an uncovering of the deceits of the Francophone system, and an affirmative construction of cultural exteriority (Dussel 94, 95). 
Hassan Mbiydzenyuy Yosimbom, "Poetic Explorations in Bill F. Ndi's Worth Their Weight in Thorns: (De)Constructing Hegemonic National Integration and Debating Francophonecentric National Governance in The Cameroons"

CLCWeb: Comparative Literature and Culture 23.4 (2021): <http://docs.lib.purdue.edu/clcweb/vol23/iss4/10> page 13 of 16

"Dream On! We'll be Loyal" marks the entrenchment of the subaltern cosmopolitan ethos in Ndi's collection. Unlike in "Crown of Plenty" where the speaker simply promised the king dissent, the speaker in "Dream On!" outrightly tells the leadership that loyalty has become a pipe dream. To the speaker, until their ships are brimmed with truth, their loyalty will beat its drum of sincerity to end their royalty; they would even be ready to beat those drums torn "when lords for their lies become thorns" (93). The speaker concludes, "We won't yield showing their betrayal/For when we did enthrone them, all they pledged/Stood miles away from lies they swore to dredge/And today their dreams to coerce /We would transport in their hearse" (93). Here the speaker signals the consequences of failed promises. The fact that the leaders have not fulfilled the promises that brought them to power indicates that power relationships are constitutive of society because those who have power construct the institutions of society according to their values and interests. That is, in Cameroon, power is exercised by means of coercion and/or by the construction of meaning in people's minds, through mechanisms of symbolic manipulation such as false promises. However, since Francophone-Anglophone societies are contradictory and conflictive, wherever there is power there is also counterpower, and that marks the capacity of Anglophone socio-economic and politico-cultural actors to challenge the power embedded in the institutions of society for the purpose of claiming representation for their own Anglo-Saxon values and interests. The actual configuration of the Cameroonian state and other institutions that regulate people's lives depends on this constant interaction between Francophone power and Anglophone counterpower. To Ndi, therefore, there is dire need for a new generation of Cameroonian leaders (who have deep love of learning) to unlearn and are on fire for justice. "Dream on!" affirms the gradual asphyxiation of AC because its official language (English), its educational system, its system of administration and governance, its legal system, and its transparent democratic processes are systematically being targeted and absorbed into the FC culture. Thus, the two All Anglophone Conferences (AAC I and II) of the early 1990s and the rise and popularity of secessionist voices were born of AC's desire for cultural preservation.

In his resignation letter from the post of first Vice President of the CPDM on June 9, 1990, J.N. Foncha cited as a reason for resigning, the fact that

deliberate lies have been said in the media to try to isolate English-speaking Cameroonians who voted for unification and subject them to hatred and discrimination and harassment by other Cameroonians and the constitution that I held and preached as the supreme law of the land is in many ways ignored or manipulated.

In recent times, Francophonecentrism's refusal to acknowledge and reward AC loyalty has polarized it into restorationist groups such as the Southern Cameroons Youth League (SCYL), the Southern Cameroons National Council (SCNC), and the Ambazonia Movement that call for the restoration of the independence of the former Trust Territory of BSC from FC/LRC. Federalists agree that Cameroon does require a federation which recognizes and preserves the region's peculiarity, as did the 1961 Federal Constitution while unitarists insist that TC is one and indivisible, that TC should be a decentralized unitary state, and that everything must be done to avoid federalism or the restoration of the independence of SC. Given that the cessation of loyalty preached and practiced by some of these groups since October 2016 has paralyzed the AC legal and school systems, Ndi's subalternist poetic vision suggests that it is imperative for the government to initiate constructive dialogue as soon as possible and agree upon a possible roadmap regarding their legitimate and genuine demands. As the Bishops pointed out in their memo cited earlier, "In the spirit of the African family, we would expect the father of the family to find out from a hurting (even if errant) child what the problem is and what they can do to alleviate their pain and suffering" (22 December 2016).

Subaltern cosmopolitanism maintains that openness to dialogue and to cooperation is required of all people of good will, and of individuals and groups with specific responsibilities in the areas of socioeconomic and political life, at both the national and international levels. From a Rosenauian perspective, it also argues that for "Francophonizing" and "Anglophonizing" tendencies "to accommodate each other, individuals have to come to appreciate that they can achieve psychic comfort in collectivities through multiple memberships and multiple loyalties" (100). Thus, Ndi's WWT argues that the notion of a FC "highest loyalty" needs to give way to the development of mutually inclusive multiple loyalties. Drawing on Rosenau's postulations once more, one could argue that the diverse multiplicity of Francophone and Anglophone opposites underlies an endless series of tensions between core and periphery, communitarianism and cosmopolitanism, cultures and subcultures, FC patriots and AC dissentients, decentralization and centralization, universalism and particularism, flow, and closure, and self and Other (25). These tensions demonstrate that there is an acute sense, of course, that the potential opened by the arrestment of loyalty/AC/SC crisis will not necessarily be realized, and that the 
Hassan Mbiydzenyuy Yosimbom, "Poetic Explorations in Bill F. Ndi's Worth Their Weight in Thorns: (De)Constructing Hegemonic

National Integration and Debating Francophonecentric National Governance in The Cameroons"

CLCWeb: Comparative Literature and Culture 23.4 (2021): <http://docs.lib.purdue.edu/clcweb/vol23/iss4/10> page 14 of 16

projects under way, especially in their restorationist/separatist form may be fragile and full of tensions and contradictions (Escobar 392). Thus, WWT offers ways of thinking about the ongoing transformations that neither shortcut their potential by interpreting them through worn out categories - political decentralization - nor that aggrandize their scope by imputing to them utopias - outright breakaway that might be far from the desires and actions of most of the actors involved (392).

This paper, therefore, asserts that it is not enough to think from the space of "Francophonecentrism"; it is necessary to incorporate other knowledge producers and forms of knowledge, such as the activistintellectuals that inhabit the worlds of AC/SC social movements and, in general, historical, and contemporary expressions of contemporary Cameroonian decolonial thought. Thus, the heterodox Anglophone are currently speaking of "relational ontologies or relational worlds and knowledges, in the sense that these worlds are built on the basis of the interconnectedness and interdependencies of everything that exists, including all kinds of entities, on the continuity between knowing, doing, and being" (Escobar 396). Also, the heterodox points at the potential for a new beginning which could bring about a reinvention of Cameroonian democracy and development. More radically still it signals the end of the predominance of a more-than-fifty-year "Francophonecentric" society and heralds one founded on "pluri-nationality" and "pluri-ethnicity," and cultural autonomy (392). Aníbal Quijano perhaps puts it better when grasping the historical specificity of such moments he calls it "a time of luchas (struggles) and of options" (qtd. Escobar 392). The current AC/SC mobilizations/struggles are, therefore, ontological-political projects. They push for non-representational politics and non-dualist understandings of socio-economic and politico-cultural worlds and in this way their politics of difference entails a political ontology. The struggles demonstrate that neither a Cameroonian Pachamama nor Sumaq Kawsay can be accommodated within hegemonic integration/governance frameworks without destabilizing them significantly. They are, indeed, unthinkable within such frameworks because they take epistemic decolonization to the very heart of politics (397).

\section{Conclusion: Asymmetric Francophone-Anglophone Ontologies and Epistemologies; Strategic Harmonization and/or a Separate Existence.}

This paper has demonstrated that at stake is how AC/SC can transcend the alterity of negative difference embedded in Francophonecentric epistemology, and whether autonomy and sovereignty are possible for AC/SC in the space-time of national governance and complex interdependence. From the poetic lens of Ndi's WWT, both are desirable, but only the first - transcending negative difference - is seemingly possible, for AC/SC is already and has always been at the center of the history of TC, notwithstanding the fantasies of a "Francophonecentric" historiography that has inferiorized AC/SC difference by turning it into a difference in time and a difference in space. Temporal differentiation is articulated in evolutionary terms and historical stages in which FC/LRC is always ahead in a social Darwinist world of linear development, initiating progressive change that Anglophones are fated to imitate. Spatial differentiation posits Francophone central and Anglophone marginal places, territorializes social development - wealth and poverty - so that levels of material accumulation become measures of human worth and historical agency in which $\mathrm{FC} / L R C$, once again, is not only placed at the center but its national expansion and interventions become imperative humanistic acts of magnanimity. Both forms of differentiation accord FC/LRC an immanent teleology and turn AC/SC history into an endless process of recapitulation.

Following the argument against hegemonic integration and governance and upholding the democratic iterations and deliberative democracy, this paper challenges the government of TC to exercise its goodwill and to regain its legitimacy by adopting a combination of elements of a Rosenauian sixgovernance typology as a panacea for Pyrrhic "Francophonecentrism" and the foundation for an allinclusive "Living Library Project" (189-91). Such a suggestion points to a strategic harmonization of mutually conciliating elements of six general forms of transregional governance. Three of these "network" governance, "side-by-side" governance, and "mobius-web" governance - reflect the complex and extensive nonlinear feedback processes that have accompanied the advent of Cameroonian fragmentation. These three can, in turn, be distinguished from three other, more straightforward forms that are less complex and more linear and familiar sources of governance: the governance-withoutgovernment or bottom-up model, the governance-by-government or top-down model, and the governance-by-market model (89). According to Rosenau, top-down governance is practiced by the government, it is formal and unidirectional (vertical or horizontal); bottom-up governance is practiced by mass publics, it is informal and unidirectional (vertical or horizontal); market governance is practiced by the government, the elite, and mass publics, it is mixed (formal and informal) and unidirectional (vertical or horizontal); network governance is practiced by the government and business alliances, it is formal and multidirectional (vertical and horizontal); side-by-side governance is practiced by the 
Hassan Mbiydzenyuy Yosimbom, "Poetic Explorations in Bill F. Ndi's Worth Their Weight in Thorns: (De)Constructing Hegemonic National Integration and Debating Francophonecentric National Governance in The Cameroons"

CLCWeb: Comparative Literature and Culture 23.4 (2021): <http://docs.lib.purdue.edu/clcweb/vol23/iss4/10 page 15 of 16

government, it is informal and multidirectional (vertical and horizontal); and mobius-web governance is practiced by the government, the elite, and mass publics, it is mixed (formal and informal) and multidirectional (vertical and horizontal) (190).

Unlike top-down, bottom-up, and market governance, "network" governance, "side-by-side" governance, and "mobius-web" governance, are not marked by processes that flow in essentially one direction. Governance-by-network model involves bargaining among equals (i.e., nonhierarchical), formally organized collectivities that ensues when the impetus for governance stems from common concerns about problems. Side-by-side governance "arises out of cooperative interchanges among nongovernmental elites and state officials that [break down] the distinction between formal and informal inputs and the two become fully intertwined and indistinguishable" (190). Mobius-web governance occurs "when networked interactions among the state, elites, and mass publics constitute a hybrid structure in which the dynamics of governance are so overlapping among the several levels as to form a singular, web-like process that, like a mobius, neither begins nor culminates at any level or at any point in time" (190).

In line with the argument of this paper, a combination of elements of the Rosenauian six-governance typology would result in interactions that constitute a hybrid non-hegemonic structure in which the dynamics of governance are so intricate and overlapping among the several levels as to form a singular "Francophonizing" and at the same time "Anglophonizing" web-like process that, like a mobius, neither begins nor culminates at any level or at any point in time. Such a combination would not culminate with the passage of a law or compliance with its regulations. Rather, it would be operative if the issues subjected to governance continue to be of concern. There would be occasional fluctuations and reversals in the patterns of interaction; it is also clear that the labels of the various forms of governance are "shorthand ways of referring to central tendencies, to the nature and essential direction of the paths along which authority and the impetus for governance flow but they also allow for [Cameroonian] nuance" (191). Such hybrid governance would mark the beginning of a genuine Cameroonian effort to recapture the self. This would create the ideal conditions of existence where instead of Francophone superiority and Anglophone inferiority, Cameroonian would quite simply attempt to touch one other, to feel the other, and to explain the other themselves (Fanon 181). Ultimately, it is imperative to reassert that the chains of hegemony are not on the Cameroonian leadership's feet, but in their minds. Therein lies the real challenge, to "de-Francophonecentric" turns and "Anglophonecentric" interventions that express a measure of optimism without, however, simplistically asserting that a nonhegemonic national integration and pluricentric governance nirvana lies ahead.

\section{Works Cited}

Bakhtin, Mikhail. "Discourse in the Novel." The Dialogic Imagination, edited by Michael Holquist. Translated by Caryl Emerson and Michael Holquist, U of Texas P, 1981, pp. 259-422.

Benhabib, Seyla. "Introduction: The Democratic Moment and the Problem of Difference." Democracy and Difference: Contesting the Boundaries of the Political, edited by Seyla Benhabib, Princton UP, 1996, pp. 3-18. The Claims of Culture: Equality and Diversity in the Global Era, Princeton UP, 2002.

The Rights of Others: Aliens, Residents, and Citizens. Cambridge UP, 2004.

- Dignity in Adversity: Human Rights in Turbulent Times, Polity Press,'2011.

Biya, Paul. "Speech of the Head of State on the occasion of the celebration of the Fiftieth Anniversary of the 'Reunification" https://www.prc.cm/en/announcements/587-speech-of-the-head-of-state-on-the-occasion-ofthe-celebration-of-the-fiftieth-anniversary-of-the-reunification

Brohed, Ulla. Library Offers, Imam, Gypsy, Gay Person for 'Loan'”, 17 August 2005, accessed, 6 December 2018 http://www.abc.net.au/news/newsitems/200508/s1439257.htm.

D'Cruz, Carolyn. Identity Politics in Deconstruction: Calculating with the Incalculable, Ashgate, 2008

Depelchin, Jacques. Silences in African History: Between the Syndromes of Discovery and Abolition, Mkuki na Nyota, 2005.

Dussel, Enrique. Philosophy of Liberation. Trans. Aquilina Martinew and Christine Morkovsky, Orbis Books, 1985.

Escobar, Aturo. "Afterword." Globalization and the Decolonial Option, edited by Walter D. Mignolo and Arturo Escobar, Routledge, 2010, pp. 391-99.

Fanon, Frantz. Black Skin White Mask. Trans. Charles Lam Markmann, Forewords by Ziauddin Sardar and Homi K. Bhabha, Pluto Press, 1986.

Ferguson, James. Global Shadows: Africa in the Neoliberal World, Duke UP, 2006.

Foncha, John Ngu. "Letter of Resignation from the CPDM," June 9, 1990.

Goldberg, Theo. "In/Visibility and Super/Vision: Fanon on Race, Veils, and Discourses of Resistance." Fanon: $A$ Critical Reader, edited by Lewis R. Gordon, T. Denean Sharpley-Whiting, and Renée T. White, Blackwell, $1996, p_{i} 179-202$.

Held, David. (2005). "Globalization: The Dangers and the Answers." Debating Globalization, edited by David Held et al, Polity Press, 2005, pp. 1-37.

hooks, bell. Yearning: Race, Gender, and Cultural Politics, South End Press, 1990.

Malik, Kenan. The meaning of Race: Race, History and Culture in Western Society, Macmillan, 1995.

Mignolo, Walter. "Foreword: On Pluriversality and Multipolarity." Constructing the Pluriverse:'The Geopolitics of Knowledge, edited by Bernd Reiter, Duke UP, 2018, pp. Ix-xvi.

. "On Plúriversality and Multipolár World Órder: Decoloniality after Decolonization; Dewesternization after the Cold War." Constructing the Pluriverse: The Geopolitics of Knowledge, edited by Bernd Reiter, Duke UP, 2018, pp. 90-116.

Ndi, Bill. Worth their Weight in Thorns. Linus Learning, 2014.

Ngứgĩ wa Thiong'o. Writers in Politics, Heinemann, 1981.

Something Torn and New: An African Renaissance. Basic Civitas Books, 2009.

Nuttal, Sarah. Beautiful Ugly: African and Diaspora Aesthetics. Duke UP, 2005 
Hassan Mbiydzenyuy Yosimbom, "Poetic Explorations in Bill F. Ndi's Worth Their Weight in Thorns: (De)Constructing Hegemonic National Integration and Debating Francophonecentric National Governance in The Cameroons"

CLCWeb: Comparative Literature and Culture 23.4 (2021): <http://docs.lib.purdue.edu/clcweb/vol23/iss4/10> page 16 of 16

Obama, Michelle. Becoming, Crown, 2018.

Ouologuem, Yambo. Bound to Violence. Trans. Ralph Manheim, Heinemann, 1971.

Ritzer, George. Globalization: The Essentials, Wiley-Blackwell, 2011.

Rosenau, James. "Governance, Order, and Change in World Politics." Governance Without Government: Order and

Change in World Politics, edited by James Rosenau and Ernst-Otto Czempiel, Cambridge UP, 1992, pp. 1-29.

. "Emergent Spaces, New Places, and Old Faces: Proliferating Identities in a Globalizing World ". Worlds on the Move: Globalization, Migration, and Cultural Security, edited by Jonathan Friedman and Shalini Randeria, I.B. Tauris, 2004 pp. 23-62.

The Study of World Politics, Volume 2: Globalization and Governance, Routledge, 2006.

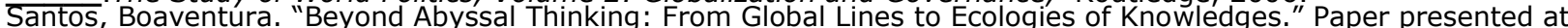

the Fernand Braudel Center, University of New York at Binghamton, October 24, 2006. The End of the Cognitive Empire: The Coming of Age of Epistemologies of the South, Duke UP, 2018. Schumpeter, Joseph. Capitalism, Socialism and Democracy, Routledge, 2006.

The Bishops' of the Ecclesiastical' Province of Bamenda. "Memorandum Presented to the Head of State, His Excellency President Paul Biya, on the Current Situation of Unrest in the Northwest and Southwest Regions of Cameroon, December 22, 2016.

Wikipedia."RwandanGenocide."AccessedApril3,2019https://en.wikipedia.org/wiki/Rwandan_genocide

Wright, Derek. "African Literature and Post-Independence Disillusionment." The Cambridge History of African and Cáribbean Literature Volume II, edited by Abiola Irele and Simon Gikandi, Cambridge UP, 2004, pp. 797-808.

Zeleza, Tiyambe. "Banishing the Silences: Towards the Globalization of African History," Paper presented at the

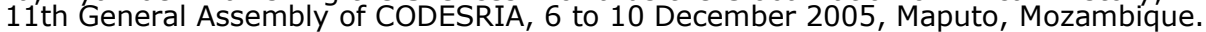

Author's profile: Hassan Mbiydzenyuy Yosimbom holds a PhD in African Literature from the University of Yaoundé 1, Cameroon. He was a 2019 ARUA-Mellon Postdoctoral Fellow at the Centre for Urban Management Studies (CUMS), University of Ghana, Legon, where he researched on "Mobility and Sociality in Africa's Emerging Urban." He is currently a Postdoctoral Fellow at the Centre for African Studies (CAS), University of Cape Town, researching on "Entanglements, Mobility and Improvisation: Culture and Arts in Contemporary African Urbanism and its Hinterlands." His research interests include identity dynamics, multiple-layered identity formations and performances, mobility, postcolonial studies, cosmopolitanism, coloniality, decoloniality and pluriversality. email: <yoshassmbiy@yahoo.com> 